\title{
Diversity and Activities of Mosquito in Yogyakarta Special Region Province, Indonesia, a Non Filariasis Endemic Area
}

\author{
Siti Istianah ${ }^{1,}$ Budi Mulyaningsih ${ }^{2}$, and Sitti R. Umniyati ${ }^{2}$ \\ ${ }^{1}$ Doctor program of Faculty of Medicine, Public Health and Nursing Universitas Gadjah Mada, Indonesia, Departement of \\ Parasitology, Faculty of Medicine, Universitas Islam Indonesia \\ ${ }^{2}$ Department of Parasitology, Faculty of Medicine, Public Health and Nursing Universitas Gadjah Mada, Indonesia
}

\begin{abstract}
According to data from the Ministry of Health of the Republic of Indonesia in 2018, there were 37 cases of Elephantiasis in Yogyakarta, even though Yogyakarta is not an endemic area of filariasis. This preliminary study was carried out to evaluate the diversity of species, relative abundance, frequency and dominance of mosquitoes in Yogyakarta and to determine the role of mosquitoes as a vector of filariasis. A cross-sectional study was used involving 3 hamlets with elephantiasis cases found in April 2019 in Yogyakarta. Mosquitoes around the house inhabited by the patient with elephantiasis were collected for 12 hours starting from 6:00 p.m. until 6:00 a.m. Mosquitoes were dissected under a dissection microscope and the presence of filaria larvae was observed. A total of 9 mosquitoes species were found. They were Culex vishnui, Culex tritaenorhynchus, Armigeres kesseli, Aedes albopictus, Culex quinquefasciatus, Culex bitaenorhynchus, Anopheles vagus, Anopheles subpictus, Aedes aegypti. The highest diversity, frequency, and dominance was Culex vishnui, while the lowest was Culex quinquefasciatus. There was no filarial larva found during the study.
\end{abstract}

Keywords: diversity, activity, mosquito, filariasis, Yogyakarta.

\section{Introduction}

Filariasis is an infectious disease caused by Nematode worm infections and is transmitted by mosquitoes. Filarial worms live in the lymphatic system, causing inflammation of the lymphatic channels and glands in the form of lymphangitis and lymphadenitis, as well as disorders of lymph flow causing an obstruction that continues into edema. Acute filariasis occurs beginning with recurrent fever, retrograde lymphangitis, and lymphadenitis. Furthermore, it can continue to become chronic filariasis in the form of edema, which is initially reversible, but at the later stages becomes irreversible due to tissue fibrosis [1].

Until now filariasis is still a health problem in Indonesia. Filariasis does not cause death, but the advanced stage of the disease causes permanent disability in the form of enlargement, namely elephantiasis, of the legs, arms, breasts, and genitals. Elephantiasis raises social and economic problems. Patient productivity has decreased to be a problem for patients and their families. State-borne health costs are also large [2]. Three species of lymphatic filarial worms are known, namely Wuchereria bancrofti, Brugia malayi and Brugia timori, and all three are found in Indonesia [3].

Filariasis is transmitted by mosquitoes. Various mosquitoes have been found to act as filariasis vectors, namely Anopheles, Culex, Mansonia, Aedes and
Armigeres [4]. There are 23 species of mosquitoes from the 5 genera known to act as filariasis vectors. Eradication of this disease cannot ignore vector control. Vector control activities must be carried out properly so that vector densities can be suppressed. Therefore, it is necessary to know vector bionomic which includes mosquito breeding sites, feeding behavior, and resting behavior.

In Indonesia, in 2017 there was 12,677 chronic filariasis (elephantiasis) cases spread in 34 provinces. This figure is lower than the data in 2016, which were 13,009 , because of reported deaths. The provinces with the most chronic filariasis cases in 2017 are Papua with 3,047 cases, while in the Special Region of Yogyakarta there are 37 chronic cases. Nevertheless, the Special Region of Yogyakarta is not a filariasis endemic area with no cases of microfilaremia found in the Special Region of Yogyakarta [3]. There is no data yet why in Yogyakarta there was no transmission of filariasis, although 37 cases of elephantiasis were found.

The purpose of this study was to determine the diversity of species, relative abundance, frequency and dominancy of mosquitoes captured in non-endemic filariasis areas in Yogyakarta.

\footnotetext{
Corresponding author: sitti-rahmah@ugm.ac.id
} 


\section{Materials and Methods}

\subsection{Study Area}

This observational study was designed to cross-sectional, carried out in 3 hamlets, namely 2 hamlets in Bantul Regency (Pandak and Sedayu sub-districts) and 1 hamlet (Ngaglik sub-district) in Sleman Regency in February 2019. Site selection is based on the presence of elephantiasis cases. This type of research is descriptive, describing the diversity of mosquitoes that have the potential to be a vector of filariasis.

\subsection{Mosquito collecting}

Collecting mosquitoes is done by mosquito catching volunteers using aspirators for 12 hours, starting at 6:00 p.m. until 6:00 a.m. inside and outside the home of the elephantiasis case and two houses in the vicinity. Each volunteer acts as a human bite and a collector. Volunteers wear closed clothes except for the lower limbs. The landed mosquitoes were captured using an aspirator, and inserted to labeled paper cups according to collection time and location.

Catching mosquitoes is carried out by the following procedure.

2.2.1. Human landing collection was performed for 40 minutes each hour inside and outside the houses

2.2.2. The resting collection was performed for 10 minutes post-human collection inside the house (walls, mosquito nets, curtains, hanging clothes) and outside the house (outside walls, drum walls, leaves), in 3 different houses

2.2.3. The identification of breeding places is carried out by observing the area around catching mosquitoes. Larvae were detected in puddles found.

The collected mosquitoes were identified using a guide to the Rampa Rattanirithikul Mosquito Identification Key Book[5,6,7].

2.2.4. Parameter

The parameters analyzed were mosquito density expressed in Man Hour Density (MHD), relative abundance, frequency and dominance numbers as described by previous researchers Indonesia [8] as follows.

MHD is a certain number of mosquitoes that land on people legs per hour in a certain time.

$\mathrm{MHD}=\frac{\text { number of mosquito in one species }}{\text { collector number } x \frac{40}{60} \times \text { time of catching }}$

Relative abundance $=$ number of mosquito in one species $\frac{\text { number of all species of mosquito }}{\text { number }} \times 100$
Species frequency numbers are comparisons between the number of mosquitoes of certain species captured with one type of catch with all mosquitoes captured with all types of arrests.

Frequency $=$ (mosquito number of one method $) /($ total mosquito number of all method)

The species dominance is the result of multiplication between relative abundance and the number of frequencies of certain types of mosquitoes caught.

Dominance number $=$ relative abundance $\mathrm{x}$ Frequency.

\section{Results and Discussion}

\subsection{Mosquito Collection}

The number of mosquitoes obtained from 3 collecting areas for 12 hours was 209 adult mosquitoes. The identification results showed as many as 9 species. They are Cx. vishnui, Cx. tritaeniorhynchus, Ar. kesseli, Ae. albopictus, Cx. quinquefasciatus, Cx. bitaeniorhynchus, An. vagus, An. subpictus, Ae. aegypti. The density of mosquitoes caught in humans (MHD) is presented in Table 1.

Table 1. Man Hour Density of mosquito collected by Human Landing collection method in 3 hamlets in Sleman Regency and Bantul Regency, Yogyakarta Special Region Province, at February 2019.

\begin{tabular}{ll}
\hline Species & MHD \\
\hline Cx.vishnui & 2,15 \\
Cx.tritaeniorhynchus & 0,33 \\
Ar.kesseli & 0,25 \\
Ae.albopictus & 0,19 \\
Cx.quinquefasciatus & 0,17 \\
Cx.bitaeniorhynchus & 0,06 \\
An.vagus & 0,04 \\
An.subpictus & 0,04 \\
Ae.aegypti & 0,02
\end{tabular}

MHD: Man Hour Density, mosquito/time (hour)/man

The relative abundance, frequency, and dominancy of mosquitoes captured by people's bait: indoor human landing collection(IHLC) and outdoor human landing collection (OHLC) and mosquitoes resting collection: indoor resting collection (IRC) and outdoor resting collection (ORC) are presented in Table 2.

Fluctuations of mosquito landing activity that occur every hour can be seen in Figure 1. The highest landing activity of mosquitoes is at $02.00-03.00$ am by the $C x$. vishnui mosquito. 
Table 2. Relative abundance, frequency and dominance number of mosquito collected by Human Landing collection method and resting mosquito collection method inside and outside houses in 3 hamlets in Sleman Regency and Bantul Regency, Yogyakarta Special Region Province, at February 2019.

\begin{tabular}{|c|c|c|c|c|c|c|c|c|c|c|c|c|}
\hline Spesies & $\begin{array}{l}\text { IHLC } \\
\text { RA }\end{array}$ & Freq & Dom & $\begin{array}{l}\text { IRM } \\
\text { RA }\end{array}$ & Freq & Dom & $\begin{array}{l}\text { OHLC } \\
\text { RA }\end{array}$ & Freq & Dom & $\begin{array}{c}\text { ORM } \\
\text { RA }\end{array}$ & Freq & Dom \\
\hline$C x .^{a}$ & 73,21 & 0,20 & 14,36 & 37,50 & 0,10 & 3,77 & 62,63 & 0,30 & 18,58 & 42,86 & 0,04 & 1,85 \\
\hline$C x .^{b}$ & 8,93 & 0,02 & 0,21 & 1,79 & 0,00 & 0,01 & 11,11 & 0,05 & 0,58 & 9,52 & 0,01 & 0,09 \\
\hline$C x .^{c}$ & 12,50 & 0,03 & 0,42 & 5,36 & 0,01 & 0,08 & 1,01 & 0,00 & 0,00 & 0,00 & 0,00 & 0,00 \\
\hline$C x .^{d}$ & 0,00 & 0,00 & 0,00 & 1,79 & 0,00 & 0,01 & 3,03 & 0,01 & 0,04 & 4,76 & 0,00 & 0,02 \\
\hline$A r .^{e}$ & 0,00 & 0,00 & 0,00 & 3,57 & 0,01 & 0,03 & 12,12 & 0,06 & 0,70 & 9,52 & 0,01 & 0,09 \\
\hline$A n .^{f}$ & 0,00 & 0,00 & 0,00 & 1,79 & 0,00 & 0,01 & 2,02 & 0,01 & 0,02 & 9,52 & 0,01 & 0,09 \\
\hline$A n .^{g}$ & 3,57 & 0,01 & 0,03 & 0,00 & 0,00 & 0,00 & 0,00 & 0,00 & 0,00 & 0,00 & 0,00 & 0,00 \\
\hline$A e^{h}$ & 0,00 & 0,00 & 0,00 & 3,57 & 0,01 & 0,03 & 8,08 & 0,04 & 0,31 & 19,05 & 0,02 & 0,36 \\
\hline$A e^{i}$ & 1,79 & 0,00 & 0,01 & 3,57 & 0,01 & 0,03 & 0,00 & 0,00 & 0,00 & 4,76 & 0,00 & 0,02 \\
\hline
\end{tabular}

\section{MHD}

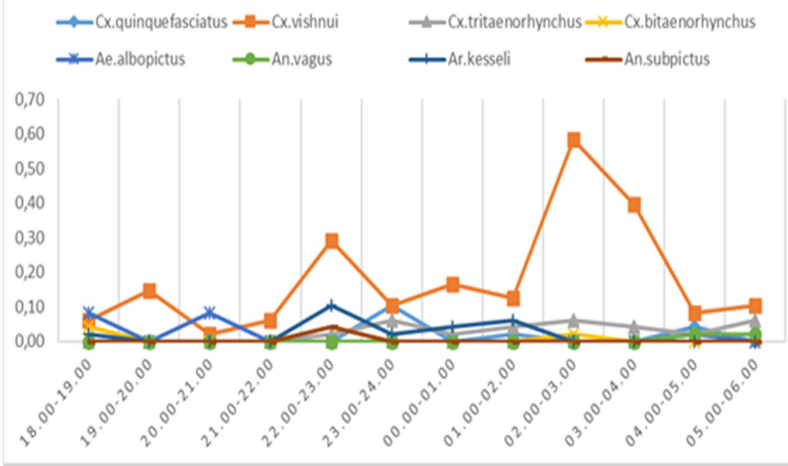

Figure 1. Man hour density of mosquitoes in 3 hamlets of Yogyakarta Special Region, collected at February 2019.

\subsection{Breeding Places}

It was found many mosquito larvae in the wood bathing pool act as mosquito breeding place in Sleman Yogyakarta Special Region (Figure 2).

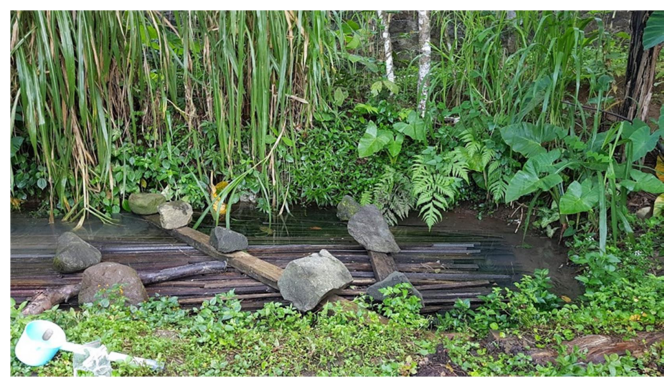

Figure 2. Wood bathing pool act as a mosquito breeding place in Sleman, Yogyakarta Special Region.

\subsection{Discussion}

The mosquito fauna found in non-endemic filariasis areas is in 3 hamlets in Sedayu sub-district and Pandak sub-district, Bantul regency and Ngaglik sub-district in Sleman Regency in February 2019 as many as 9 species. The diversity of mosquito fauna depends on the local geographical conditions. These two sub-districts in Bantul and 1 sub-district in Sleman are plains with altitudes less than $500 \mathrm{~m}$ above sea level $(9,10)$. This area includes relatively flat urban areas with both artificial and natural puddles. Artificial puddles such as fish ponds, wood bathing pools and others (Figure 2). These puddles act as mosquito breeding places of Culex spp. i.e. $C x$. vishnui and $C x$. quinquefasciatus.

The high density of mosquito species in an area is one of the success factors in transmitting vector borne diseases. High mosquito populations are associated with the availability of mosquito breeding sites. Table 1 . shows that the dominant species is $C x$. vishnui with MHD 2.15 mosquitoes per hour per person. Other mosquitoes found with lower densities are $C x$. tritaeniorhynchus, Ar. kesseli, Ae. albopictus, Cx. quinquefasciatus, Cx. bitaeniorhynchus, An. vagus, An. subpictus, Ae. aegypti. Lymphatic filariasis found in Java is an urban type bancrofti filariasis with confirmed vector, namely $C x$. quinquefasciatus. In this study the density of $C x$. quinquefasciatus was in level 5, which was 0.17 mosquitoes per hour per man. This finding supports the fact why the Special Region of Yogyakarta is categorized as non filariasis endemic areas. According to Hairston and de Meillon that the occurrence of filariasis transmission is required $+15,000$ infective bites, so a high mosquito density is needed [11].

The mosquito biting behavior of the $C x$. quinquefasciatus species is more dominant indoor than outdoor. Likewise, the resting behavior of the mosquito, 
they prefer to rest indoor rather than outdoor. This result is in accordance with previous studies on the biting behavior of $C x$. quinquefasciatus in other regions[12]. However, relative abundance and frequency of $C x$. quinquefasciatus is much lower than $C x$. vishnui mosquitoes. This result supports preliminary data that Yogyakarta Special Region is nonfilariasis endemic area. Dominance numbers of mosquito can describe actual population density. In this study the dominance of $C x$. vishnui mosquitoes was the highest compared to other species. On the contrary, the dominance of $C x$. quinquefasciatus was lower.

The results of this study indicate that $\mathrm{Cx}$. quinquefasciatus mosquitoes that have low density, low relative abundance, low frequency, and low dominance do not support the occurrence of lymphatic filariasis transmission in the Yogyakarta Special Region. The $C x$. vishnui mosquito which has high density, high relative abundance, high frequency, and high dominancy does not play a role in the transmission of lymphatic filariasis. It is reported that $C x$. vishnui is one of the vectors of Japanese encephalitis in Indonesia [3]. In the future, research is needed to determine whether mosquitoes captured in the study area have the potential to be vectored by DNA testing and infection testing.

\section{Conclusion}

The mosquito fauna found in Yogyakarta Special Region consists of 9 species of mosquitoes, namely $C x$. vishnui, Cx. tritaeniorhynchus, Ar. kesseli, Ae. albopictus, Cx. quinquefasciatus, Cx. bitaeniorhynchus, An. vagus, An. subpictus, Ae. aegypti. Mosquitoes that have the highest relative abundance and the highest dominancy are Cx.vishnui, while the Cx.quinquefasciatus has a low relative abundance and low dominance. This result supports that there is no potential vector transmission of lymphatic filariasis in the Yogyakarta Special Region.

\section{Acknowledgments}

The author would like to thank the head of Bantul District Health Office, Sleman District Health office, and the Head of Parasitology Department of Faculty of Medicine, Public Health and Nursing Universitas Gadjah Mada for permission to carry out this research. Many thank also the Research Directorate, Gadjah Mada University, for funding through the student final assignment recognition (Rekognisi Tugas Akhir) 2019 period. Thanks are also due to technicians for their valuable assistance in the laboratory. This study obtained approval from the Medical and Health Research Ethics Committee.

\section{References}

1. WHO: Lymphatic Filariasis Practical Entomology. Adv Parasitol [Internet]. 2010;72:205-33. Available from: www.who.intHO. 2016.
2. WHO: Global Programme to Eliminate Lymphatic Filariasis: Progress Report 2000-2009 and Strategic Plan 2010-2020 [Internet]. Global Programme to Eliminate Lymphatic Filariasis: Progress Report 20002009 and Strategic Plan 2010-2020. 2010. Available from: Departement of Control of Neglected Tropical Diseases (NTD), Geneva, Switzerlandijaya DC.

3. Kementerian Kesehatan Republik Indonesia. Profil kesehatan Indonesia Tahun 2017 [Internet]. Kurniawan R, Yudianto, Hardhana B, Siswanti T, editors. Jakarta: Kementerian Kesehatan Republik Indonesia; 2018. Available from: http://www.kemkes.go.id

4. WHO. Defining the Roles of Vector Control and Xenomonitoring in the Global Programme to eliminate: Report of the Informal Consultation. WHO CDC, Prvention Erad Parasit Dis Vector Control. 2002;(January):29-31.

5. Rattanarithikul R, Harrison BA, Harbach RE, et al. : Illustrated Keys To The Mosquitoes of Thailand II. Culex. The Southeast Asian J Trop Med Public Health. 2005; 36(2):1-97.

6. Rattanarithikul R, Harrison BA, Harbach RE, et al. : Illustrated Keys To The Mosquitoes of Thailand IV. Anopheles. The Southeast Asian J Trop Med Public Health. 2006; 37(2):1- 90

7. Rattanarithikul R, Harrison BA, Harbach RE, et al. : Illustrated Keys To The Mosquitoes of Thailand VI. Aedini. The Southeast Asian J Trop Med Public Health. 2010; 41 (1).

8. Pratiwi R, Anwar C, Salni, et al. : Species Diversity and Community Composition of Mosquitoes in a filariasis endemic area in Banyuasin District, South Sumatra, Indonesia. Biodiversitas. 2019; 20 (2): 453-462.

9. Pemerintah Kabupaten Bantul: Data Pokok Pembangunan.https://bantulkab.go.id/datapokok/0403_t inggi_tempat.html, accessed 30 Juni 2019

10. Pemerintah Kabupaten Sleman, Sosial dan Kependudukan,https://slemankab.bps.go.id/statictable/20 17/11/09/106/luas-daerah-menurut-ketinggian-daripermukaan-laut-di-kabupaten-sleman-2016.html, accessed 30 Juni 2019.

11. Hairston NG, de Meillon B: On the inefficiency of transmission of Wuchereria bancrofti from mosquito to human host. Bull World Health Organ. 1968; 38(6):935-41.

12. Ramadhani $T$, Yunianto B: Aktivitas Menggigit Nyamuk Culex quinquefasciatus Di Daerah Endemis Filariasis Limfatik Kelurahan Pabean Kota Pekalongan Provinsi Jawa Tengah. Aspirator. 2009;1(1):11-5.

13. Garjito TA, Widiarti, Anggrain YM, et al. : Japanese Encephalitis in Indonesia: An Update on Epidemiology and Transmission Ecology. Actatrop: 2018; 187:240-247. 